УДК 35

\title{
Розвиток системи місцевого самоврядування в Україні
}

\author{
Є.I. БOPOAIH, T.M. TAPACEHKO \\ Аніпропетровський регіональний інститут Аержавного управАіння \\ Національної акалемії державного управління при Презилентові України, \\ м. Аніпропетровськ, Україна, E-mail: e.i.borodin@vidr.dp.va
}

\section{Авторське резюме}

Статтю присвячено дослідженню питання розвитку системи місцевого самоврядування в Україні. Особливу увагу приділено розгляду елементів цієї системи в умовах реформаційних змін у місцевому самоврядуванні та територіальної організації влади в Україні. На основі аналізу законодавчих актів робиться спроба виділити особливості підходу до визначення системи місцевого самоврядування на різних етапах розвитку держави.

Ключові слова: система місцевого самоврядування, реформування місцевого самоврядування та територіальної організації влади, територіальна громада, добровільне об'єднання територіальних громад.

\section{The development of local government in Ukraine}

\author{
YE.I. BORODIN, T.M. TARASENKO \\ Dnipropetrovsk regional institute of public administration of National \\ academy for public administration under the President of Ukraine, \\ Dnipropetrovsk, Ukraine, E-mail: e.i.borodin@vidr.dp.ua
}

\begin{abstract}
The article studies the development of local government in Ukraine. Particular attention is paid to elements of the system in the Reformation of changes in local government and territorial organization of power in Ukraine. Based on the analysis of legislation is an attempt to highlight the features of the approach to the definition of local government at various stages of development.

Key words: system of local government, local government reform and territorial organization of government, local community, voluntary association of local communities.
\end{abstract}

Постановка проблеми. Розвиток місцевого самоврядування в сучасних умовах став важливим вектором суспільної трансформації. Перехід від вироблення концепції реформування місцевого самоврядування та територіальної організації влади до практичних дій потребуе втілення теоретичних положень у законодавство, що регулюе місцеве самоврядування як складову сфери публічного управління.

Важливим з цієї точки зору $є$, зокрема, питання щодо основних складових системи місцевого самоврядування в Україні.

У сучасній науковій літературі питання системи місцевого самоврядування в Україні та їі складових знайшло своє ви- світлення в публікаціях В. Вакуленка, М. Баймуратова, О. Батанова, П. Біленчука, В. Борденюка, І. Дробота, В. Кампо, В. Кравченка, В. Куйбіди, В. Олуйка, М. Орлатого, В. Погорілка та інших дослідників. Проте виникає потреба звернутися до проблеми системи місцевого самоврядування в Україні у зв'язку з процесом змін, який розпочався в останній період розвитку держави.

Метою дослідження є аналіз системи місцевого самоврядування в Україні як об'єкт реформування.

Виклад основного матеріалу. Запровадження поняття «система місцевого самоврядування» в нормативному полі публічного управління в Україні відбулося невдовзі перед здобуттям Україною неза-

(C) Є.I. Бородін, Т.M. Тарасенко 2015 
лежності, коли було ухвалено закон «Про місцеві Ради народних депутатів Української РСР та місцеве самоврядування» від 7 грудня 1990 р., який у зазначеному вигляді діяв до березня 1992 р. Стаття 2 зазначеного документа отримала назву «Система місцевого самоврядування», в якій перелічувалися наступні складові елементи:

- сільські, селищні, районні, міські, районні в містах, обласні Ради народних депутатів та їх органи;

- органи територіального громадського самоврядування (комітети і ради мікрорайонів, житлових комплексів, домові, вуличні, квартальні, дільничні, селищні, сільські комітети та інші органи);

- місцеві референдуми, загальні збори (сходи) громадян, інші форми безпосереднього волевиявлення населення, передбачені законодавством Української PCP [5].

В нашій публікації ми використовуємо широко розповсюджений в науковій літературі термін «елемент системи місцевого самоврядування». Зазначимо, що у законодавстві робилися спроби використати інші поняття, зокрема, «ланка місцевого самоврядування». В Законі України «Про місцеві Ради народних депутатів Української РСР та місцеве самоврядування» від 7 грудня 1990 р. зазначалося, що основною ланкою в системі місцевого самоврядування є місцеві Ради народних депутатів, які «на своїй території об’єднують і координують діяльність усіх інших ланок місцевого самоврядування» [5].

Таке розширене трактування системи місцевого самоврядування, яке, як ми бачимо, включало не тільки елементи цієї системи, а ще й перелік форм волевиявлення та участі членів територіальної громади (за термінологією того часу - населення або громадян), вже тоді потребувало відповідної корекції. Проте невдовзі після ухвалення нової редакції зазначеного Закону "Про місцеві Ради народних депутатів та місцеве і регіональне самоврядування» від 26 березня 1992 р. поняття «система місцевого самоврядування» виглядала майже так само:

- сільські, селищні, міські Ради народних депутатів та їх органи;
- інші форми територіальної самоорганізації громадян (громадські комітети і ради мікрорайонів, житлових комплексів, домові, вуличні, квартальні, дільничні, селищні, сільські комітети і форми безпосереднього волевиявлення населення - місцеві референдуми, загальні збори (сходи) громадян) [2].

Фактично у 1992 р. відбулося зменшення кількості елементів місцевого самоврядування до двох за рахунок поєднання в єдиний блок органів самоорганізації населення та форм волевиявлення населення. Привертає увагу та обставина, що до березня 1992 р. районні у містах ради стояли в одному ряду з сільськими, селищними, міськими та обласними радами, а з ухваленням нової редакції закону їх було вилучено з цього переліку, але тим не менше присвячено окрему частину відповідної статті: «районні в містах Ради народних депутатів є складовою частиною міського самоврядування» [2].

Особливістю внесених у 1992 р. змін було те, що при визначенні системи місцевого самоврядування в Україні знову використовувалося поняття «ланка місцевого самоврядування», яке прямо не розшифровувалося. «Сільські, селищні, міські Ради народних депутатів об’єднують і координують на своїй території діяльність інших ланок місцевого самоврядування», - йшлося в тексті документа.

Додамо до цього, що Закон України «Про місцеві Ради народних депутатів та місцеве i регіональне самоврядування» від 26 березня 1992 р. використовував на рівні з поняттям «місцеве самоврядування» ще й «регіональне самоврядування» та визначав наступне: «Систему регіонального самоврядування становлять районні і обласні Ради народних депутатів, місцеві референдуми в межах території району, області, інші форми самоорганізації громадян районів і областей» [2].

Ухвалення в 1996 р. Конституції незалежної України закріпило загальні засади місцевого самоврядування, яке, на відміну від попереднього періоду, вже відокремлювалося від державної влади, суттєво вплинуло на підходи щодо формування структури поняття «система місцевого самоврядування в Україні». 
Зазначений термін у тексті Конституціі не використовувався, проте були сформульовані визначення, які пізніше будуть систематизовані в базовому законі про самоврядування. В документі знайшли своє закріплення саме поняття «місцеве самоврядування», а також такі визначення, як «територіальна громада», «сільські, селищні, міські ради», "сільський, селищний, міський голова», "районні та обласні ради», «органи самоорганізації населення», "виконавчий орган ради». В Основному Законі всі ці поняття не було об'єднано в єдину систему.

Найбільшою зміною, яку запроваджувала Конституція України, у порівнянні з попередніми підходами щодо визначення елементів системи місцевого самоврядування стало поняття «територіальна громада», під яким розумілося: «жителі села чи добровільне об'єднання у сільську громаду жителів кількох сіл, селища, міста». Саме місцеве самоврядування стало визначатися як «право територіальної громади самостійно вирішувати питання місцевого значення». В законі України «Про місцеві Ради народних депутатів та місцеве і регіональне самоврядування» від 26 березня 1992 р. місцеве самоврядування в Україні визначалося як «територіальна самоорганізація громадян для самостійного вирішення безпосередньо або через органи, які вони обирають, усіх питань місцевого життя» [2]. Стаття 141 Конституції запровадила поняття «сільський, селищний, міський голова», визначивши, що обрання його здійснює територіальна громада на основі загального, рівного, прямого виборчого права шляхом таємного голосування. На зміну поняттю «форми (органи) самоорганізації населення» прийшло поняття «органи самоорганізації населення». У Конституції йшлося наступне: «сільські, селищні, міські ради можуть дозволяти за ініціативою жителів створювати будинкові, вуличні, квартальні та інші органи самоорганізації населення і наділяти їх частиною власної компетенції, фінансів, майна» [1].

Звертаємо увагу, що в Конституціі України 1996 р. було дещо по-іншому закріплено питання щодо місцевого самоврядування на рівні районів у містах. У тексті Основного Закону було закріплено наступне: «Питання організації управління районами в містах належить до компетенції міських рад» (ст. 140) [1]. Як відомо, в Конституції УРСР статус районних у місті Рад знайшов своє безпосереднє закріплення (розділ V).

В Законі України «Про місцеве самоврядування в Україні» від 21 травня 1997 р. знайшло своє закріплення як поняття «система місцевого самоврядування», так і перелік їі складових. До речі, саме термін «система місцевого самоврядування» не було включено до тексту документа. До системи місцевого самоврядування на момент запровадження оновленого законодавства з питань самоврядування було включено такі елементи:

- територіальна громада;

- сільська, селищна, міська рада;

- сільський, селищний, міський голова;

- виконавчі органи сільської, селищ ної, міської ради;

- районні та обласні ради, що представляють спільні інтереси територіальних громад сіл, селищ, міст;

- органи самоорганізації населення [4].

Проте зазначений перелік, який був, так би мовити, «нормативним» для України в цілому містив ще й один «факультативний» елемент у вигляді «районної у місті ради». В текст статті 5 «Система місцевого самоврядування» зазначеного закону увійшли дві частини. Зміст першої викладено вище, а в другій викладено наступне: «У містах з районним поділом за рішенням територіальної громади міста або міської ради відповідно до цього Закону можуть утворюватися районні в місті ради. Районні в містах ради утворюють свої виконавчі органи та обирають голову ради, який одночасно $є$ i головою iї виконавчого комітету» [4].

Визначення окремих елементів системи місцевого самоврядування у вигляді основних термінів знайшло своє відображення в статті 1 Закону України «Про місцеве самоврядування в Україні». До них належать такі: «територіальна громада», «районні та обласні ради», «виконавчі органи рад», 
«органи самоорганізації населення» [4].

Ухвалена Кабінетом Міністрів України 1 квітня 2014 р. «Концепція реформування місцевого самоврядування та територіальної організації влади в Україні» визначає основні шляхи вирішення проблем існуючої системи місцевого самоврядування. Ключовими питаннями, які визначають сутність змін цієї системи, є: визначення обгрунтованої територіальної основи для діяльності органів місцевого самоврядування та органів виконавчої влади; створення належних матеріальних, фінансових та організаційних умов для забезпечення здійснення органами місцевого самоврядування власних і делегованих повноважень; розмежування повноважень між органами місцевого самоврядування та органами виконавчої влади на різних рівнях адміністративнотериторіального устрою за принципами субсидіарності та децентралізації; максимальне залучення населення до прийняття управлінських рішень, сприяння розвитку форм прямого народовладдя [7]. Після цього на забезпечення розвитку системи місцевого самоврядування було спрямовано прийняття таких законів України як «Про співробітництво територіальних громад» (від 17 червня 2014 № 1508-VII), «Про добровільне об'єднання територіальних громад" (від 5 лютого 2015 р. №157-VII), «Про засади державної регіональної політики» (від 5 лютого 2015 р. № 156-VIII).

Прийняття нових законодавчих актів спричинило внесення змін до такого концептуального поняття, як «система місцевого самоврядування», що знайшло відображення у змінах до Закону України «Про місцеве самоврядування в Україні», внесених 5 лютого 2015 р. Після доопрацювання до переліку елементів цієї системи віднесено:

- територіальну громаду;

- сільську, селищну, міську раду;

- сільського, селищного, міського голову;

- виконавчі органи сільської, селищної, міської ради;

- старосту;

- районні та обласні ради, що представляють спільні інтереси територіальних громад сіл, селищ, міст;
[4].

- органи самоорганізації населення

Крім того, законом закріплено, що у містах 3 районним поділом за рішенням територіальної громади міста або міської ради можуть утворюватися районні в місті ради [4]. Тобто, необов'язковий елемент системи місцевого самоврядування у вигляді районної у місті ради зберіг своє право на існування.

Як бачимо, від часу ухвалення Закону України «Про місцеве самоврядування в Україні» у травні 1997 р. до лютого 2015 р. при описі системи місцевого самоврядування в Україні використовувалися поняття, які відображають населення («територіальна громада»), органи місцевого самоврядування (сільські, селищні, міські ради, виконавчі органи сільської, селищної, міської ради, районні та обласні ради), органи самоорганізації населення (сільські, селищні, міські ради). На новому етапі розвитку нормативно-правової бази розширення відбулося за рахунок збільшення елементів 3 категорії посадових осіб місцевого самоврядування.

Закріплення поняття «староста» в нормативно-правову базу місцевого самоврядування відбулося шляхом включення до Закону України «Про місцеве самоврядування в Україні» додаткової статті $14^{1}$ з однойменною назвою. У законі визначено, що староста обирається у селах, селищах, визначених за рішенням місцевої ради об'єднаної територіальної громади, за винятком адміністративного центру, на строк повноважень місцевої ради. Законодавчо було закріплено, що «староста є посадовою особою місцевого самоврядування». Положення про старосту має затверджуватися сільською, селищною, міською радою об'єднаної територіальної громади, при цьому у зазначеному документі мають бути відображені права і обов'язки старости, порядок його звітності, інші питання, пов'язані з діяльністю старости. Закон передбачив, що староста є членом виконавчого комітету ради об'єднаної територіальної громади [3].

Появі поняття «староста» передувала робота з пошуку назви посади, обсягу іiі повноважень та статусу. Так, в одному 3 варіантів урядового проекту Зако- 
ну України «Про право територіальних громад на об'єднання» (№ 3849 від 8 січня 2014 р.) пропонувалося ввести поняття «уповноважена особа в селі (селищі)». Порядок заміщення такої посади пропонувався менш демократичний та прозорий. Цю «уповноважену особу» мав би подавати на затвердження ради об'єднаної територіальної громади відповідний голова ради. За задумкою розробників, нереалізованих на практиці пропозицій «уповноважена особа в селі (селищі)» мала б отримати суттєво нижчий статус представника виконавчого комітету місцевих рад об'єднаної територіальної громади в селі (селищі) та право участі з правом дорадчого голосу у засіданнях виконавчого комітету місцевої ради тільки під час розгляду тих питань, що мали стосуватися саме його села (селища) [6].

Розгляд елементів системи місцевого самоврядування дозволяє також відзначити те, що залишається остаточно невизначеним питання подальшого розвитку такого елемента як райони у містах. В Україні організація управління в містах 3 районним поділом здійснюється на основі трьох моделей управління на рівні існуючих районів у містах: існування районних адміністрацій (в тому числі районні державні адміністрації як орган виконавчої влади у місті Києві та як виконавчі органи міської ради); існування районних у місті рад з власними виконавчими органами; існування i районних у місті рад, і районних адміністрацій. Як i в попередні роки, так і зі змінами 2015 р. у Законі України «Про місцеве самоврядування в Україні» за ними залишається статус факультативного або асоційованого елемента місцевого самоврядування. Особливістю статусу районів у містах є те, що вони не мають конституційного статусу, питання організації управління районами в містах належить до компетенції міських рад. Аналіз вітчизняної практики свідчить про існування сьогодні тенденції ліквідації районних у містах рад на основі прийняття відповідних рішень міськими радами. Така тенденція $є$ наслідком поступового обмеження з боку міських рад діяльності органів місцевого самоврядування районів у містах шляхом забирання наданих раніше повноважень. Не дає відповіді на питання подальших шляхів врегулювання такої ситуації й «Концепція реформування місцевого самоврядування та територіальної організації влади в Україні». Стосовно районів у містах у Концепції зазначається лише існування конфлікту компетенції між органами місцевого самоврядування внаслідок перебування територіальної громади міста у складі територіальної громади району в місті. Пошук шляхів розв'язання зазначеної проблеми потребує грунтовного аналізу та осмислення як з боку науковців, так і практиків. До найбільш значущих змін у системі місцевого самоврядування останнього періоду необхідно віднести перегляд підходу до визначення «територіальної громади» як базового елемента системи місцевого самоврядування в Україні. У попередні роки у ст. 6 Закону України «Про місцеве самоврядування в Україні" мова йшла про те, що територіальні громади сусідніх сіл можуть об'єднуватися в одну територіальну громаду, створювати єдині органи місцевого самоврядування та обирати єдиного сільського голову. При цьому таке об'єднання та вихід із складу сільської громади мали відбуватися за рішенням місцевих референдумів відповідних територіальних громад сіл. Тобто мова йшла про можливість об'єднання в межах однієї територіальної громади лише сусідніх сіл та на основі референдуму.

У 2015 р. після прийняття Закону України «Про добровільне об'єднання територіальних громад» до профільного закону було внесено зміни до ст. 6 «Територіальні громади». Так, у статті зазначається, що територіальні громади можуть об'єднуватися в одну сільську, селищну, міську територіальну громаду, утворювати єдині органи місцевого самоврядування та обирати відповідно сільського, селищного, міського голову. Територіальні громади, що добровільно об'єдналися, можуть вийти із складу об'єднаної територіальної громади в порядку, визначеному законом [4; 3]. Тим самим у сучасному нормативно-правовому полі з'являється можливість для до- 
бровільного об'єднання територіальних громад не тільки суміжних сіл, але й селищ та міст. Це положення знаходить своє продовження в конкретизації того, що «об'єднана територіальна громада, адміністративним центром якої визначено місто, є міською територіальною громадою, центром якої визначено селище, селищною, центром якої визначено село, - сільською [3].

Тобто відбулася зміна підходу до визначення меж територіальної громади, яка розглядається ширше, ніж лише населений пункт - село, селище, місто. Відповідно, створюються умови для перегляду існуючої територіальної основи для організації влади на місцях та оновлення «базового рівня» адміністративно-територіального устрою, яким $\epsilon$ адміністративно-територіальні одиниці - громади. Незмінним залишається розгляд територіальної громади як первинного суб'єкта місцевого самоврядування, основного носія його функцій і повноважень, яким $\epsilon$ територіальна громада села, селища, міста. Подальша конкретизація статусу територіальної громади передбачає визначення їі правового статусу.

Крім того, добровільність як принцип об'єднання територіальних громад ставить питання про те, чи стане поширеною практика такого об'єднання? Також залишається питання, яким чином будуть відбуватися подальші зміни територіальної основи місцевого самоврядування на інших субрегіональних рівнях, передусім, на рівні району? Який шлях обере Україна: добровільного чи примусового об'єднання? В країнах ЄС, у тому числі постсоціалістичних, застосовувалися обидва шляхи.

Висновки. Від створення засад місцевого самоврядування в Україні питання щодо системи місцевого самоврядування знаходиться в центрі уваги дослідників та практиків публічного управління. Виділення окремих елементів зазначеної системи мало свої особливості на різних етапах розвитку української державності. Так, була спроба до елементів цієї системи віднести форми безпосередньої участі громадян у вирішенні питань місцевого значення. 3 ухваленням нової Конституції закріпилось наступне бачення системи місцевого самоврядування в Україні: територіальна громада; сільська, селищна, міська рада; сільський, селищний, міський голова; виконавчі органи сільської, селищної, міської ради; районні та обласні ради; органи самоорганізації населення. Процес децентралізації влади в Україні привів до перегляду бачення зазначеного питання. В системі місцевого самоврядування 3'явилося поняття «староста», нового змісту набуло поняття «територіальна громада». На порядку денному розв'язання питання щодо таких елементів, як «районна, обласна рада», "районна у місті рада», поглиблення поняття «територіальна громада» з урахуванням можливості добровільного об'єднання територіальних громад. Подальшого наукового дослідження потребують перспективи розвитку окремих елементів системи місцевого самоврядування в контексті адміністративно-територіального устрою та місцевого самоврядування в Україні.

СПИСОК АIТЕРАТУРИ:

1. Конституція України : прийнята на п’ятій сесії Верховної Ради України 28 червня 1996

p. - Режим доступу : http://zakon2.rada.gov.ua/laws/show/254/96-вр.

2. Про внесення змін до Закону Української РСР «Про місцеві Ради народних депутатів

Української РСР та місцеве самоврядування» : закон України від 26 березня 1992 року

№ 2234-XII // Відомості Верховної Ради України. - 1992. - № 28. - Ст. 387.

3. Про добровільне об'єднання територіальних громад : закон України від 5 лютого 2015 р.

№ 157-VIII. - Режим доступу : http://zakon4.rada.gov.ua/laws/show/157-19.

4. Про місцеве самоврядування в Україні : закон України від 21 травня 1997 р. № 280/97-

BP. - Режим доступу : http://zakon4.rada.gov.ua/laws/show/280/97-вр.

5. Про місцеві Ради народних депутатів Української РСР та місцеве самоврядування : закон

України від 7 грудня 1990 р. № 533-XII // Відомості Верховної Ради України. - 1991. -

№ 2. - Ст. 5 .

6. Про право територіальних громад на об'єднання : проект Закону України від 8 січня 2014 р.

№ 3849 - Режим доступу : http://w1.c1.rada.gov.ua/pls/zweb2/webproc4_1?pf3511=49447. 
7. Про схвалення концепції реформування місцевого самоврядування та територіальної організації влади в Україні : розпорядження Кабінету Міністрів України від 1 квітня 2014 p. № 333-p. - Режим доступу : http://zakon2.rada.gov.ua/laws/show/333-2014-p. publish/article?art_id=248081369\&cat_id=244274160.

\section{REFERENCES:}

1. Konstytutsiya Ukrayiny : pryynyata na p"yatiy sesiyi Verkhovnoyi Rady Ukrayiny 28 chervnya $1996 \mathrm{r}$. (The Constitution of Ukraine, adopted at the fifth session of the Verkhovna Rada of Ukraine June 28, 1996). - Mode of access : http://zakon2.rada.gov.ua/laws/ show/254/96-vr.

2. Pro vnesennya zmin do Zakonu Ukrayins'koyi RSR «Pro mistsevi Rady narodnykh deputativ Ukrayins'koyi RSR ta mistseve samovryaduvannya» : zakon Ukrayiny vid 26 bereznya 1992 roku № 2234-XII (On Amendments to the Ukrainian Law «On Local Council of People’s Deputies of the Ukrainian SSR and local government”: the law of Ukraine on March 26, 1992 № 2234XII)// Vidomosti Verkhovnoyi Rady Ukrayiny. - 1992. - № 28. - St. 387.

3. Pro dobrovil'ne ob"yednannya terytorial'nykh hromad : zakon Ukrayiny vid 5 lyutoho 2015 r. № 157-VIII (On a voluntary association of local communities: the law of Ukraine on February 5, 2015 p. № 157-VIII). - Mode of access : http://zakon4.rada.gov.ua/laws/show/157-19.

4. Pro mistseve samovryaduvannya v Ukrayini : zakon Ukrayiny vid 21 travnya 1997 r. № 280/97-VR. (On local government in Ukraine: Ukraine Act of 21 May 1997 p. № 280/97-VR). Mode of access : http://zakon4.rada.gov.ua/laws/show/280/97-vr.

5. Pro mistsevi Rady narodnykh deputativ Ukrayins'koyi RSR ta mistseve samovryaduvannya : zakon Ukrayiny vid 7 hrudnya 1990 r. № 533-XII (On the Local Council of People’s Deputies of the Ukrainian SSR and local government: Law of Ukraine dated December 7, 1990 p. № 533-XI) // Vidomosti Verkhovnoyi Rady Ukrayiny. - 1991. - № 2. - St. 5.

6. Pro pravo terytorial'nykh hromad na ob"yednannya : proekt Zakonu Ukrayiny vid 8 sichnya 2014 r. № 3849 (On the right of local communities to unite the draft Law of Ukraine on January 8, 2014 p. № 3849). - Mode of access : http://w1.c1.rada.gov.ua/pls/zweb2/ webproc4 1 ? pf $3511=49447$.

7. Pro skhvalennya kontseptsiyi reformuvannya mistsevoho samovryaduvannya ta terytorial'noyi orhanizatsiyi vlady v Ukrayini : rozporyadzhennya Kabinetu Ministriv Ukrayiny vid 1 kvitnya 2014 r. № 333-r (On approval of the concept of local government reform and territorial organization of power in Ukraine, the Cabinet of Ministers Ukraine on April 1, 2014 p. № 333-p). - Mode of access : http://zakon2.rada.gov.ua/laws/show/333-2014-r.

Бородін Свгеній Іванович - доктор історичних наук, професор Дніпропетровський регіональний інститут державного управління Національної академії державного управління при Президентові України Адреса: 49044, м. Дніпропетровськ, вул. Гоголя, 29 E-mail: e.i.borodin@vidr.dp.ua

Тарасенко Тетяна Миколаївна - кандидат наук з державного управління, доцент Дніпропетровський регіональний інститут державного управління Національної академії державного управління при Президентові України Адреса: 49044, м. Дніпропетровськ, вул. Гоголя, 29

E-mail: tarasenkotatiana@rambler.ru

Borodin Yevhenii Ivanovych - doctor of historical sciences, Full Prof.

Dnipropetrovsk regional institute of public administration of National academy for public administration under the President of Ukraine

Address: 29, Gogol Str., Dnipropetrovsk, 49044, Ukraine

E-mail: e.i.borodin@vidr.dp.ua

Tarasenko Tetyana Mykolayivna - PhD in public administration, associate professor Dnipropetrovsk regional institute of public administration of National academy for public administration under the President of Ukraine Address: 29, Gogol Str., Dnipropetrovsk, 49044, Ukraine E-mail: tarasenkotatiana@rambler.ru 